\title{
PENGARUH PENGGUNAAN MODEL STUDENT FACILITATOR AND EXPLAINING TERHADAP KEMAMPUAN BERPIDATO OLEH SISWA KELAS XII SMA SANTO THOMAS 3 MEDAN
}

\author{
Maria Wea ${ }^{1}$, Losten Tamba \\ *1. Penulis \\ *2. Pembimbing \\ Program Studi Pendidikan Bahasa Indonesia,FakultasKeguruan dan Ilmu Pendidikan, Universitas Katolik \\ Santo Thomas, Jl. Setia Budi No. 479-F Tanjung Sari Medan - Kode Pos No. 20132, email- \\ audinamia@yahoo.co.id
}

Abstrak

Penelitian ini bertujuan untuk mengetahui pengaruh penggunaan model student facilitator and explaining terhadap kemampuan berpidato yang baik. Penelitian ini dilakukan di SMA Santo Thomas 3 Medan pada bulan Agustus 2017. Populasi penelitian ini berjumlah 197 siswa dan sampel diambil dengan teknik simple random sampling sebanyak 80 siswa. Metode penelitian ini adalah metode eksperimen pos-testonly control designyang dilaksanakan pada dua kelompok. Instrumen yang digunakan untuk menjaring data adalah tes lisan dalam bentuk penugasan yaitu berpidato. Pengujian hipotesis dilakukan dengan menggunakan uji " $t$ ". Hasil pengolahan data statistik menunjukkan bahwa kemampuan dalam berpidato dengan menggunakan model student facilitator and explaining termasuk dalam kategori baik dengan nilai rata-rata 80.12, sedangkan kemampuan berpidato tanpa menggunakan model student facilitator and explaining termasuk dalam kategori cukup dengan nilai rata-rata 63.75 selanjutnya pengujian hipotesis menunjukkan $t_{\text {hitung }} 6.22$ kemudian dikonsultasikan dengan tabel pada taraf signifikan 0.05 dengan dk 78 adalah 1.99. Oleh karena $t_{\text {hitung }}$ yang diperoleh lebih besar dari $\mathrm{t}_{\text {tabel }} 6,22>1.99$ maka terbukti bahwa hipotesis nihil $\left(\mathrm{H}_{0}\right)$ ditolak dan hipotesis alternatif $\left(\mathrm{H}_{\mathrm{a}}\right)$ diterima maka dapat disimpulkan bahwa model student facilitator and explaining berpenggaruh positif terhadap kemampuan berpidato pada siswa kelas XII SMA Santo Thomas 3 Medan Tahun Pembelajaran 2017/2018.

Kata Kunci: model student facilitator and explaining dan model berpidato

\section{Abstract}

This study aims to know the effect of student facilitator and explaining model to make a speech. This study was conducted at SMA Santo Thomas 3 Medan in August 2017. The population of this study numberd 197 students and the sample that was taken by using random sampling technique numbered 80 students. The method used in this study is an postestonly control experimenta design conducted in two groups. The instrument used to collect the data is a test essay in the form of assignment to make a speech. Hypothesis testing is done by using test " $t$ ". Based on the results of processing statistical data showing that the ability to make a speech by using student facilitator and explaining model in good category with an average value of 80.12 . While the ability to make a speech without using student facilitator and explaining model included in the enough category with the average value of 63.75 . Furthermore, the hypothesis test shows is 6.22 then consulted with t table at significant level $\alpha=0,05$ with $\mathrm{dk}=78$ is 1.99 . Therefore, it is proved that the null hypothesis $\left(H_{o}\right)$ is rejected and the alternative hypothesis $\left(H_{a}\right)$ is received. So, it can be concluded that the student facilitator and explaining model is effective significantly to make a speech of the twelfth grade Student of OF SMA Santo Thomas 3 Medanon academic year 2017/2018

Key Words: student facilitator and explaining, speech 


\section{PENDAHULUAN}

Bahasa sangat penting dalam kehidupan manusia.Manusia menjadikan bahasa sebagai alat komunikasi yaitu sarana menyampaikan gagasan, pesan, atau maksud kepada orang lain. Dengan bahasa, manusia dengan mudah dan bebas untuk menyampaikan masa lalu, masa sekarang, dan masa yang akan datang. Selain alat komunikasi, bahasa digunakan untuk menyatakan ekspresi diri atau ungkapan emosional dari berbagai aspek. Selanjutnya, bahasa dapat digunakan sebagai kontrol sosial atau dijadikan alat untuk mempengaruhi orang lain agar orang dapat berubah pola pikir, sikap, dan perilaku.

Hal yang penting lagi, bahasa dapat digunakan sebagai alat untuk beradaptasi dan berbaur dengan orang lain. Keterampilan menggunakan bahasa

mencakup keterampilan dalam menyampaikan atau menuangkan ide secara lisan atau tertulis serta kemamapuan dalam menyerap informasi secara lisan dan tertulis. Keterampilan berbahasa memiliki empat komponen, yaitu a) keterampilan menyimak (listening skills), b) keterampilan berbicara (speaking skills),c) keterampilan membaca (rading skills), dan d) keterampilan menulis (writing skills).

Keterampilan berbahasa lisan yaitu menyimak dan berbicara, sedangkan keterampilan berbahasa tulisan berhubungan dengan keterampilan membaca dan menulis. Tarigan ( 1981: 15). Kemampuan berbicara adalah kemampuan seseorang dalam mengungkapkan ide, perasaan, dan pikiran secara lisan dengan tujuan tertentu, agar pesan yang disampaikan dapat dipaham oleh orang lain. Ada beberapa aspek keterampilan berbicara yang dilatih dalam pembelajaran bahasa Indonesia yang dianggap penting untuk masa sekarang ini misalnya diskusi dalam berbagai bentuk, wawancara, kotbah, kata sambutan, pidato, dan presentasi ilmiah. Latihan terhadap materi berbicara ini sangat menunjang seseorang dapat berbicara dengan berani, lancar, sistematis, dan lengkap. Latihan berbicara yang ada disekolah dibuat secara kontinu dan terpadu dengan keterampilan berbahasa lain.

Materi keterampilan berbicara sudah lama bagian dalam pembelajaran bahasa di sekolah dasar dan menengah, namun keadaan kemampuan berbicara pembelajar tidak maksimal. Pada saat ini, sangat minim siswa yang mampu berbicara dengan baik. Keadaan sekarang memperlihatkan krisis orang-orang yang mampu berbicara. Ketidakmampuan tersebut dapat dilihat dari penguasaan materi bicara, pengorganisasiannya, kelancaranya, dan lain-lain yang bersifat nonlinguistik lainnya seperti keberanian untuk berani di depan umum.

Seperti pembelajaran ini, kualitas pembelajaran bahasa Indonesia, khususnya keterampilan berbahasa, dipengaruhi oleh beberapa aspek, misalnya minat dan bakat pembelajar.Siswa yang mempunyai minat dan bakat berbicara dengan baik.Kondisi kehidupan dirumah yang demokratis juga berpengaruh terhadap kebiasaan dan keberanian dalam berbicara. Keadaan tertentu juga dapat memaksa seseorang ituselalu berlatih berbicara.Selain itu, kemampuan guru dalam mengajarkan materi bicara juga sangat berpengaruh terhadap minat siswa dalam berbicara dengan media, pendekatan, model, strategi, atau metode pengajar.

Menyikapi kondisi tersebut diatas, salah satu aspek yang dapat dilakukan adalah dengan memilih model pembelajaran yang tepat. Model pembelajaran yang dianggap tepat dalam meningkatkan keterampilan berbicara siswa adalah model pembelajaran Student Facilitator and Explaining. Model ini dianggap mampu menciptakan suasana belajar yang aktif dan tidak membosankan. Setiap siswa bertanggung jawab terhadap tugas pribadi atau kelompok. Selain itu, setiap siswa saling mengeluarkan ide untuk memahami 
suatu konsep dan menyelesaikan tugas sehingga terbentuk pemahaman belajar yang mampu bertahan lama. Melalui metode ini, penyajian bahan ajar tidak membosankan lagi karena siswa diberi waktu untuk berdiskusi dan bermain peran sehinggan keseluruhan siswa sama-sama memperoleh manfaat melalui aktivitas belajar ini. Jadi,selama proses belajar mengajar diharapkan semua siswa aktif karena pada akhirnya nanti masing-masing mengembangkan potensi mengungkapkan gagasan pendapat.

\section{KAJIAN KEPUSTAKAAN}

Menurut Soekanto (Shoimin 2014: 23), model pembelajaran adalah kerangka konseptual yang melukiskan prosedur yang sistematis dalam mengorganisasikan pengalaman belajar untuk mencapai tujuan belajar tertentu, dan berfungsi sebagai pedoman bagi para pengajar dalam merencanakan aktivitas belajar mengajar.

Joice (Tiranto2014:52) mengemukakan bahwa model pembelajaran adalah suatu perencanaan atau pola yang dapat kita gunakan untuk mendesain pola-pola mengajar secara tatap muka di dalam kelas atau mengatur tutorial, dan untuk menentukan materi atau perangkat pembelajaran termasuk di dalamnya bukubuku, film-film, tipe-tipe, program-program media komputer, dan kurikulum.

\section{Ciri-ciri Model Pembelajaran}

Rusma (2013:136) mengemukakan ciri-ciri model pembelajaran adalah sebagai berikut :

1. Berdasarkan teori pendidikan dan teori belajar dari para ahli tertentu. Model ini dirancang untuk melatih partisipasi dalam kelompok secara demokratis.

2. Mempunyai misi atau tujuan pendidikan tertentu, misalnya model berpikir induktif dirancang untuk mengembangkan proses berpikir induktif.

3. Dapat dijadikan pedoman untuk perbaikan kegiatan belajar mengajar di kelas, misalnya model synectic dirancang untuk memperbaiki kreativitas dalam pelajaran mengarang.

4. Memiliki bagian-bagian model yang dinamakan : (1) langkah-langkah pembelajaran (syntax), (2) adanya prinsip-prinsip reaksi, (3) sistem sosial, dan (4) sistem pendukung. Keempat bagian tersebut merupakan pedoman praktis bila guru akan mengadakan suatu proses pembelajaran.

5. Memiliki dampak sebagai akibat terapan model pembelajaran. Dampak tersebut meliputi : (1) dampak pembelajaran, yaitu hasil belajar yang dapat diukur, (2) dampak pengiring, yaitu hasil belajar jangka panjang.

6.Membuat persiapan mengajar (desain instruksional) dengan pedoman modelpembelajaran yang dipilihnya.

\section{Model Pembelajaran Student Facilitator} and Explaining

Shoimin (2014:83) mengemukakan bahwa model pembelajaran student facilitator and explaining merupakan salah satu tipe pembelajaran kooperatif yang menekankan pada struktur yang berkenan dirancang untuk mempengaruhi pola interaksi peserta didik dan memiliki tujuan untuk meningkatkan penguasaan materi. Penerapan model pembelajaran harus bisa memperbanyak pengalaman serta meningkatkan motivasi belajar yang mempengaruhi keaktifan belajar peserta didik, yaitu dengan menggunakan model pembelajaran student facilitator and explaining.

Kurniasih dan Sani (2015:79) berpendapat bahwa model pembelajaran student facilitator and explaining merupakan model pembelajaran yang melatih siswa untuk mempresentasikan ide atau gagasan mereka pada teman-temannya. Model pembelajaran ini akan relevan apabila siswa secara aktif ikut serta dalam merancang materi pembelajaran yang akan dipresentasikan.

\section{Kelebihan dan Kekurangan Model Pembelajaran StudenFacilitator and Explaining}


Kelebihan dan kekurangan model pembelajaran student facilitator and explaining, menurut Shoimin (2013:184185), adalah sebagai berikut:

1. Kelebihan:

a. Materi yang disampaikan lebih jelas dan konkret.

b. Dapat meningkatkan daya serap siswa karena pembelajaran dilakukan dengan demonstrasi.

c. Melatih siswa untuk menjadi guru karena siswa diberikan kesempatan untuk mengulangi penjelasan guru yang telah dia dengar.

d. Memacu motivasi siswa untuk menjadi yang terbaik dalam menjelaskan materi ajar.

e. Mengetahui kemampuan siswa dalam menyampaikan ide atau gagasan.

2. Kekurangan:

a. Siswa yang malu tidak mau mendemonstrasikan apa yang diperintahkan oleh guru kepadanya atau banyak siswa yang kurang aktif.

b. Tidak semua siswa memiliki kesempatan yang sama untuk melakukannya atau menjelaskan kembali kepada teman-temannya karena keterbatasan waktu pembelajaran.

c. Adanya pendapat yang sama sehingga hanya sebagai saja yang terampil.

d. Tidak mudah bagi siswa untuk membuat peta konsep atau menerangkan materi ajar secara ringkas.

Langkah-langkah Penggunaan Model Pembelajaran Student Facilitator and Explaining

Shoimin (2013 :184) mengatakan bahwa ada beberapa langkah-langkah model pembelajaran student facilitator and expalining sebagai berikut :

1. Guru menyampaikan materi dan kompentensi yang ingin dicapai.

2. Guru mendemonstrasikan atau menyajikan garis-garis besar materi pembelajaran.
3. Memberikan kesempatan kepada siswa untuk menjelaskan kepada siswa lainnya, misalnya melalui bagan atau peta konsep. Hal ini bisa dilakukan secara bergiliran.

4. Guru menyimpulkan ide atau pendapat dari siswa.

5. Guru menerangkan semua materi yang disajikan saat itu.

6. Penutup.

\section{Pengertian Berbicara}

Menurut Tarigan (2018:16), berbicara merupakan suatu alat untuk mengkomunikasikan gagasan-gagasan yang disusun serta dikembangkan sesuai dengan kebutuhan-kebutuhan sang pendengar atau penyimak. Pamungkas (2012:40) mengatakan bahwa berbicara merupakan salah satu jenis komunikasi selain komunikasi tertulis.Berbicara juga disebut komunikasi lisan.Dalam komunikasi lisan syarat mutlak yang harus ada adalah adanya komunikator (pembicara) dan komunikan (lawan bicara). Antara komunikator dan komunikan akan terbangun komunikasi efektif apabila pesan yang disampaikan oleh komunikator bisa dipahami oleh komunikan sehingga terjadi interaksi komunikasi.

Tantawai (2015: 126) berpendapat bahwa berbicara adalah mengungkapkan pikiran secara langsung atau tidak langsung.Berbicara secara langsung adalah pembicara berhadapan langsung dengan pendengarnya, sedangkan berbicara tidak langsung adalah pembicara tidak berhadapan langsung dengan pendengarnya.Berdasarkan pendapat para ahli di atas, dapat disimpulkan bahwa berbicara adalah sebuah pemikiran yang baik secara langsung maupun dalam pemikiran tidak langsung.

\section{Tujuan Berbicara}

Tarigan (2018:15) mengemukakan bahwa tujuan berbicara adalah untuk berkomunikasi agar dapat menyampaikan pikiran secara efektif. Untuk itu pembicara memahami makna segala sesuatu yang ingin dikomunikasikan, harus mampu mengevaluasi efek komunikasinya terhadap pendengarnya, serta harus mengetahui 
prinsip-prinsip yang mendasari segala situasi pembicaraan, baik secara umum maupun secara perorangan. Tarigan juga mengemukakan maksud umum dari berbicara, yaitu :

1. Memberitahukan dan melaporkan (to inform).

2. Menjamu dan menghibur (to entertain).

3. Membujuk, mengajak, mendesak, dan meyakinkan (to persuade).

\section{Ragam Seni Berbicara}

Tarigan(2008:24-25) mengemukakan bahwa ada baiknya kita mengenal ragamragam seni berbicara terlebih dahulu. Secara garis besar, berbicara (speaking) dapat dibagi atas beberapa bagian antara lain sebagai berikut:

1. Berbicara di muka umum pada masyarakat (publik speaking) yang mencakup empat jenis, yaitu :

a. Berbicara dalam situasi-situasi yang bersifat meberitahukan atau melaporkan, yang bersifat informatif (informative speaking).

b. Berbicara dalam situasi-situasi yang bersifat kekeluargaan, persahabatan (fellowship speaking).

c. Berbicara dalam situasi-situasi yang bersifat membujuk, mengajak, mendesak, dan meyakinkan ( persuasive speaking).

d. Berbicara dalam situasi-situasi yang bersifat merundingkan dengan tenang dan hati-hati ( deliberative speaking).

2. Berbicara pada konferensi ( conference speaking) yang meliputi :

a. Diskusi kelompok (group discussion), yang dapat dibedakan atas

1) Tidak resmi (informal), dan masih dapat diperinci lagi atas:

a) Kelompok Studi (studi group).

b) Kelompok pembuat kebijaksanaan (policy making groups).

c) Komik

2) Resmi (formal) yang mencakup pula:
a) Konferensi
b) Diskusi panel
c) Simposium

3) Prosedur parlementer (parliamentary prosedure)

\section{Pengertian Pidato}

Sumarna (2016:9) mengemukakan bahwa pidato merupakan penyampaian suatu uraian lisan mengenai suatu hal, atau bisa juga diartikan sebagai penyampaian sebuah pesan tertentu kepada banyak pihak dengan harapan agar para pendengar (audiens) bisa memahami atau setidaknya bisa mengerti akan pesan-pesan yang disampaikan. Pidato merupakan sebuah aktivitas atau kegiatan seseorang dalam menyampaikan berbagai pesan tertentu kepada orang lain dengan tujuan agar orang tersebut bisa mengerti dan memahami dengan penuh kesadaran tentang segala hal yang telah disampaikan melalui pidatonya.

Bahar (2015:9) mengemukakan bahwa pidato merupakan penyampaian gagasan, pikiran atau informasi. Bahar mengemukakan pidato merupakan the art of persuasion, yaitu seni membujuk atau mempengaruhi. Berpidato bukanlah suatu pekerjaan yang sederhana karena dalam berpidato menyangkut beberapa unsur penting seperti : pembicara, pendengar, tujuan dan isi pidato, persiapan, teknik dan etika dalam berpidato, serta masih banyak hal lain yang menjadi perhatian. Dalam Kamus Besar Bahasa Indonesia edisi ketiga (Depdiknas, 2003:871) dinyatakan bahwa pidato adalah pengungkapan pikiran dalam bentuk kata-kata yang dituju kepada orang lain, juga dikatakan bahwa pidato adalah wacana yang disiapkan untuk diucapkan di depan khayalan.

\section{Bentuk-bentuk Pidato}

Sumarna (2016:10) mengatakan bahwa bentuk-bentuk pidato disesuaikan dengan kepentingan, situasi, dan kondisi, serta tingkat kecerdasan, maupun latar belakang pendidikan, budaya, dan adat istiadat sasaran yang akan diberikan penerangan atau penjelasan. Beberapa macam bentuk pidato yaitu :

\section{Mass Information}


Penerangan umum massa, pidato akbar di depan puluhan ribu massa, baik yang majemuk maupun hanya terdiri dari satu atau dua golongan masyarakat saja (penerangan umum masa).

Ada beberapa kiat agar sukses dalam membawakan pidato di depan massa yang banyak, yaitu:

a. Menguasai teknik pidato yang gegap gempita dan menggamparkan.

b. Bersikap tegas.

c. Lantang dalam berbicara, dengan intonasi yang tegas dan jelas.

d. Perbanyak uraian yang bisa disimpulkan secara praktis.

e. Hindari pengulangan frasa agar tidak menjemukan.

f. Berikan tekanan pada kata-kata yang menyentuh jiwa dan aspirasi massa.

g. Hindari melukai hati massa, junjunglah martabat dan aspirasi massa agar mendapatkan simpati.

h. Selipkan beberapa humor untuk membangkitkan antuiasme.

2. Ceramah

Penyampaian uraian secara mendalam oleh seseorang ahli dalam bidangnya di hadapan audiens dengan jumlah yang terbatas, misalnya berkisar antara 25 orang sampai 500 orang (penerangan terbatas secara mendalam).

Pidato berbentuk ceramah memiliki ketentuan sebagai berikut:

a. Penceramah menguasai betul materi yang disampaikan.

b. Yang diundang untuk menghadiri ceramah, terbatas pada mereka yang dianggap mampu mencernah materi ceramah yang disampaikan.

c. Materi ceramah disampaiakan secara sistematis, dimulai dengan pembukaan, inti, penutup

d. Disetiap materi ceramah disertai dengan data-data maupun fakta-fakta untuk membuktikan kebenarannya

3. Up-Grading

Biasanya up - grading diberikan misalnya oleh kepala dinas kepada para bawahan, atau oleh seorang tenaga ahli yang diundang untuk memberikan penataran tentang sebuah pengetahuan yang dianggap perlu untuk meningkatkan kualitas kerja para karyawan (penataran atau peningkatan kemampuan ).

Pemberi Up-Grading hendaknya memperhatikan dua hal utama berikut:

a. Menguasai betul materi yang akan diberikan kepada para peserta $U p$ Grading

b. Materi harus dipersiapkan selengkap mungkin karena menyangkut berbagai sektor yang saling berhubungan

\section{Coaching}

Penerangan yang sifatnya edukatif karena tujuan utamanya adalah untuk memberikan pelatihan (menyampaikan penerangan dengan pelatihan).

5. Face to face

6. Penerangan yang menyampaikan dengan cara bertatap muka antara seorang juru penerang kepada seseorang atau banyak orang (dengan bertata muka). Face to face ini dilakukan terhadap orang-orang terkemuka dan berpengaruh, tujuannya adalah agar mereka nantinya dapat mengembangkan kreativitasnya sendiri dalam memberikan penerangan.

\section{Huisbezoek}

Berkunjung ke rumah orang-orang tertentu untuk menyampaikan suatu hal (ajangsana dari rumah ke rumah).

\section{Sifat dan Ciri-ciri Pidato}

Sumarna ( 2016: 15-17) mengatakan bahwa ada tiga sifat utama antara lain sebagai berikut:

1. Informatif

Berisi penjelasan yang mengemukakan hal-hal yang sesungguhnya, mengutamakan fakta, data-data, dan disertai alasan-alasan yang obyektif. Pidato informatif memiliki sifat-sifat sebagai berikut:

a. Obyektif artinya apa adanya. Dasarnya adalah memberi penerangan sejelasjelasnya dan tidak menyimpang dari pokok persoalannya. 
b. Realistis artinya berdasarkan kenyataan, baik itu kenyataan manis maupun kenyataan pahit, tanpa ada upaya untuk memoles dan menutup-nutupinya.

c. Motivatif artinya memberi pengarahan agar diperoleh kesadaran atau sikap baru yang lebih baik.

d. Zakelijk artinya tidak menyimpang dari permasalahan.

2. Propaganda

Pidato yang bersifat propaganda memiliki ciri-ciri sebagai berikut :

a. Subyektif artinya menyimpang dari hakikat kebenaran demi tercapainya tujuan.

b. Fiktif artinya cenderung mengemukakan imajinasi yang indah-indah, fatamorgana, dan isapan jempol.

c. Pemutarbalikan fakta artinya segala hal yang dilakukan demi memperoleh simpati masyarakat.

d. Agitatif artinya gaya bicara yang menyala-nyala, berapi-api, dan bombastis dan upaya meyakinkan audiens.

e. Demagogis artinya mengisi pengarahanpengarahan yang memperbodoh dan menyesatkan orang lain, bahkan kadang disertai fitnah dan adu domba.

f. Agresif artinya pidato yang bersikap menyerang pihak lain.

g. Menarik artinya pidato yang bersifat propaganda walaupun cenderung bersifat tidak baik, tapi biasanya malah sering mendapatkan tepukan tangan yang meriah dari audiens dengan tingkat kecerdasan yang pas-pasan.

3. Edukatif

Pidato yang bersifat biasanya berdasarkan pada ilmu pengetahuan dan mengikuti ketentuan-ketentuan obyektif yang bisa mempertanggungjawabkan dari segi politik, sosial budaya, maupun ilmu pengetahuan. Pidato edukatif memiliki ciri-ciri sebagai berikut:

a. Obyektif artinya menurut pada apa yang dituju atau dimaksud.

b. Rasional artinya berdasarkan pada akal sehat dan bukan pada emosi semakin, serta cenderung

mengedepankan kebenaran.

c. Wettenschpplijk artinya

berdasarkan pada ilmu pengetahuan

yang bisa dipertanggungjawabkan

kebenaran ilmiahnya.

d. Defensif artinya bersifat mempertahankan kebenarannya.

e. Tenang dalam penyampaian artinya tidak tergesa-gesa atau memaksa dalam mengemukakan pendapat agar dipahami oleh audiens.

\section{Hal-hal dalam Berpidato}

Adha (2016:58) berpendapat bahwa ada beberapa tips yang perlu diperhatikan ketika sedang berbicara di depan umum yaitu

1. Volume Suara. Volume suara seseorang bisa menunjukan seberapa besar rasa percaya dirinya. Seorang pembicara yang baik akan berbicara dengan keras dan jelas, karena ia percaya bahwa orangorang akan mendengarkan apa yang ia sampaikan. Meningkatkan range vokal pada seseorang tanpa mempedulikan jenis suara, salah satu diantaranya adalah melalui teknik "vokal kepala" atau yang disebut suara langit-langit.

2. Tempo (kecepatan). Seorang pembicara yang takut dan tidak memiliki kepercayaan diri biasanya akan gugup dalam berbicara. Tiba-tiba temponya akan menjadi rendah, keringat, terbatabata dan salah tingkah didepan panggung.

3. Intonasi. Dalam pidato bisa membuat orang mengantuk apabila terlalu monoton, sehingga orang akan bosan mendengarkan suara dan akhirnya mengantuk. Salah satu cara melatih intonasi suara adalah dengan latihan tertawa, marah, sedih, bahagia, kecewa, dan juga kalut. Jika pembicara dapat melakukan semua dengan benar, maka akan tahu bagaimana mengekspresikan suara berdasarkan perasaan tersebut.

4. Nada suara. Salah satu faktor yang cukup menentukan dalam pidato adalah nada suara.Untuk melatih nada suara, 
dibutuhkan banyak latihan seperti latihan pernafasan dengan diafragma.

5. Kefasihan dalam berbicara. Kefasihan dalam berbicara juga merupakan salah satu cara untuk berbicara di depan umum. Banyak orang yang malu berbicara di depan umum, karena merasa dirinya belum bisa berbicara di depan umum.

Ada beberapa cara untuk melatih agar bisa menjadi orang yang fasih dalam berbicara di depan umum:

a. Pertambah dan perbarui kosakata yang dimiliki, jika terpaksa harus menggunakan bahasa asing, usahakan untuk mengambil kata-kata asing yang memang sudah lazim didengar oleh masyarakat luas.

b. Latihan untuk terus berbicara dan lihatlah, apakah sudah mengalami perkembangan dalam kosakata, pemilihan kata dan masih banyak lagi.

c. Tunjukan kemampuan dalam berbicara di depan teman-teman, dan mintalah kepada mereka untuk mengoreksi jika ada kesalahan atau kekurangan dalam kalimat yang diucapkan.

Sumarna

(2016:23-32)

mengemukakan bahwa cara yang perlu dipersiapkan dalam berpidato yaitu:

1. Persiapan. Persiapan yang dilakukan dengan sempurna akan berpengaruh sangat signifikan terhadap performance dan segala pesan yang disampaikan ketika berpidato. Persiapan yang dilakukan saat berpidato yaitu:
a. Persiapan secara fisik
b. Persiapan secara mental
c. Persiapan secara teknis

2. Belajar, berpikir, dan berlatih. Ada banyak materi-materi yang bisa membantu kita dalam belajar dan berlatih untuk berbicara dimuka umum. Misalnya dengan membaca buku-buku panduan dan tata cara berpidato yang baik, mengasah keberanian dan berlatih berbicara dimuka umum.

3. Penguasaan gaya dan gerak. Gerak tubuh dan ekpresi wajah berperan besar dan menentukan keberhasilan seseorang dalam menyampaikan materi pidatonya mampu menguasai dan bisa melihat situasi dan kondisi.

4. Sistematika. Sebelum berpidato ada beberapa sistematika yang secara umum dapat dipelajari yaitu:

a. Bagian awal pidato

b. Bagian inti, tentang tujuan dari pidato.

c. Bagian akhir pidato, kesimpulan atau penutup.

\section{Hasil Penelitian yang Relevan}

Hasil penelitian yang relevan dengan penelitian tentang ketrampilan berbicara dengan berbagai model, strategi, metode yang dilakukan oleh peneliti sebelumnya yaitu:

1. Mira (2012) melakukan penelitian yang berjudulModel Pembelajaran dengan Menggunakan Model Impromtupada Siswa Kelas VII SMP PGRI Karangpawita Garut Bandung. Siklus tindakan I 73,13\% (tinggi), siklus II $75,03 \%$ (sedang), siklus I diperoleh nilai rata-rata 68,44\% (cukup). Dari hasil tersebut disimpulkan bahwa penggunaan model pembelajaran maupun media sangat berpengaruh terhadap kemampuan berbicara dalam berpidato.

2. Chihat Maichel Simare Mare (2014) melakukan penelitian yang berjudul Efektifitas Model Pembelajaran Langsung terhadap Kemampuan Berpidato Siswa Kelas XII Swasta Santa Lusia Sei Rotan. Rata-rata kelas eksperimen 76,875, sedangkan untuk kelas kontrol adalah 71,125. Dapat disimpulkan bahwa model pembelajaran memiliki pengaruh yang signifikan terhadap ketrampilan berbicara

3. Desty Junita Sihotang (2014) melakukan penelitian yang berjudul Pengaruh Model Pembelajaran Student Facilitator and Explaining terhadap Kemampuan Menulis Teks Berita oleh Siswa Kelas VIII SMP Negeri 1 Bosar Maligas”. Nilai rata-rata kelas eksperimen adalah 76,875 sedangkan untuk kelas kontrol adalah 71,125. Berdasarkan penelitian tersebut 
disimpulkan model pembelajaran memiliki pengaruh terhadap ketrampilan berbicara dalam pidato.

\section{METODELOGI PENELITIAN}

Dalam suatu penelitian, setiap penelitian terlebih dahulu harus menentukan metode yang digunakan atau jenis penelitian yang digunakan. Metode ataupun jenis penelitian sangat berperan penting, karena sebagai kegiatan yang dilakukan dalam upaya menentukan dan membuktikan sesuatu sepenuhnya tergantung kepada metode yang digunakan. Adapun metode penelitian yang digunakan dalam penelitian ini adalah metode eksperimen dengan jenis penelitian kuantitatif. Sugiono (2012:107) mengemukakan bahwa metode penelitian eksperimen dapat diartikan sebagai metode penelitian yang digunakan untuk mencari pengaruh perlakuan tertentu terhadap yang lain dalam kondisi yang terkendalikan.

Sundayana (2015:15) mengemukakan, populasi adalah sebagai keseluruhan subjek atau objek yang menjadi sasaran penelitian yang mempunyai karakteristik tertentu. Arikunto (2016:173) menyatakan bahwa populasi adalah keseluruhan subjek penelitian. Apabila seseorang ingin meneliti semua elemen yang ada diwilayah penelitian, maka penelitiannya merupakan penelitian populasi. Populasi yang dinyatakan dalam penelitian ini adalah seluruh siswa kelas XII SMA Santo Thomas 3 Medan tahun pelajaran 2017/2018. Jumlah populasi penelitian ini sebanyak 197 orang siswa .

$$
\mathrm{t}_{\mathrm{o}}=\frac{M_{1}-M_{2}}{S E_{M_{1}-M_{2}}}
$$

\section{HASIL PENELITIAN DAN PEMBAHASAN}

Dari hasil penelitian yang dilakukan tanpa menggunakan model pembelajaran student facilitator and explaining terhadap kemampuan berpidato dalam penilaiannya terbagi dalam lima kategori, yaitu kategori sangat baik sebanyak 1 orang atau 2,5\%, kategori baik sebanyak 15 siswa atau 37,5\%, kategori cukup sebanyak 16 siswa atau 40\%, kategori kurang sebanyak 8 siswa atau $20 \%$, dan kategori tidak baik sebanyak 0 siswa atau $0 \%$.

Hal ini terbukti dari hasil penelitian yang menunjukan bahwa kemampuan berpidato dengan menggunakan model Student Facilitator and Explaining terbagi dalam lima kategori, yaitu siswa yang mencapai kategori sangat baik sebanyak 22 orang atau 55\%, kategori baik sebanyak 11 siswa atau $27,5 \%$, kategori cukup sebanyak 5 siswa atau $12,5 \%$, kategori kurang sebanyak 2 siswa atau 5\%, dan kategori tidak baik sebanyak 0 siswa atau $0 \%$.

\section{SIMPULAN, IMPLIKASI DAN SARAN Simpulan}

1. Pembelajaran kemampuan berpidato siswa kelas XII SMA Santo Thomas 3 Medan tahun pembelajaran 2017/2018 tanpa menggunakan model student facilitator and explaining yaitu rata-rata nilai siswa sebesar 63,75 dan standar deviasinya sebesar 11,02. Selanjutnya jika dilihat dari kecenderungan nilai kelaskontrolkategori sangat baik sebanyak 1 orang atau $25 \%$, kategori baik sebanyak 15 siswa atau 37,5\%, kategori cukup sebanyak 16 siswa atau 40\%, kategori kurang sebanyak 8 siswa atau $20 \%$, dan kategori tidak baik sebanyak 0 siswa atau $0 \%$.

2. Pembelajaran kemampuan berpidato siswa kelas XII SMA Santo Thomas 3 Medan tahun pembelajaran 2017/2018 dengan menggunakan model student facilitator and explaining yaitu rata-rata nilai siswa sebesar 73,12 dan standar deviasinya sebesar 12,27. Selanjutnya jika dilihat dari kecenderungan nilai kelaseksperimenkategori sangat baik sebanyak 22 orang atau 55\%, kategori baik sebanyak 11 siswa atau 27,5\%, kategori cukup sebanyak 5 siswa atau $12,5 \%$, kategori kurang sebanyak 2 siswa atau 5\%, dan kategori tidak baik sebanyak 0 siswa atau $0 \%$. 
3. Penggunaan modelstudent facilitator and explaining berpengaruh signifikan terhadap kemampuan siswa dalam berpidato kelas XII SMA Santo Thomas 3 Medan tahun pembelajaran 2017/2018. Hal tersebut terbukti dari hasil rata-rata kontrol sebesar 63,75 atau kategori cukup. Sedangkan hasil eksperimen sebesar 73,12 atau kategori baik.

\section{Implikasi}

Hasil penelitian ini memberikan implikasi secara teoretis maupun praktis, adapaun implikasinya yaitu sebagi berikut:

1. Implikasi Teoretis

Temuan peneliti ini memberikan bukti secara ilmiah bahwa penggunaan model student facilitator and explaining berpengaruh signifikan terhadap kemampuan berpidato. Temuan penelitian ini juga memberikan bukti bahwa dengan penggunaan model student facilitator and explaining mampu merangsang siswa untuk mengembangkan ide atau kreativitas yang siswa miliki. Ketika menerapkan model ini peneliti menyediakan gambaran tentang pidato untuk dikembangkan dengan pengalaman yang pernah siswa alami.

2. Implikasi Praktis

a) Implikasi penelitian ini terhadap siswa yaitu, penelitian ini menunjukkan bahwa pembelajaran berpidato dengan menggunakan model student facilitator and explaining berpengaruh dalam menumbuhkan kemauan dan minat siswa dalam berpidato.

b) Implikasi penelitian ini terhadap guru yaitu, jika guru ingin hasil yang sesuai dengan penelitian ini maka guru dapat menggunakan model student facilitator and explaining, karena model pembelajar an ini mampu merangsang untuk menumbuhkan minat pada diri siswa dalam berpidato. Dalam model student facilitator and explaining siswa diharapkan mampu berpidato dengan semaksimal mungkin.

c) Implikasi penelitian ini terhadap pembaca yaitu, dengan membaca hasil dari penelitian facilitator and explainingdalam berpidato.

d) Implikasi penelitian ini terhadap peneliti yaitu, hasil penlitian ini menunjukkan pengaruh yang signifikan terhadap kemampuan berpidato, dengan demikian peneliti mendapatkan wawasan baru tentangmodel student facilitator and explaining.

\section{Keterbatasan Penelitian}

\begin{tabular}{lrr}
\multicolumn{1}{c}{ Dalam } & \multicolumn{2}{c}{ penelitian yang } \\
dilaksanakan, & terdapat & keterbatasan \\
penelitian yang & dialami penulis, yaitu \\
sebagai berikut: & &
\end{tabular}

1. Kurang disiplin waktu khususnya guru mata pelajaran sebelumnya, sehingga waktu yang seharusnya diisi oleh peneliti menjadi kurang maksimal.

2. Pada saat penelitin menyuruh siswa untuk berpidato ada sebagian siswa yang masih belum percaya diri untuk berpidato didepan kelas.

3. Penelitian ini dilaksanakan menjelang peringatan 17 Agustus, sehingga peneliti tidak maksimal untuk melakukan penelitian dengan alasan adanya kegiatan perlombaan di sekolah.

\section{Saran}

Berdasarkan pembahasan dan kesimpulan dari hasil penelitian di atas, maka penulis memberikan saran sebagai berikut.

1. Berdasarkan hasil penelitian, disarankan agar guru bahasa Indonesia di SMA Santo Thomas 3 Medan hendaknya menggunakan model student facilitator and explaining untuk materi berpidato sebagai salah satu teknik alternatif mengajar kepada siswa, karena terbukti bahwa nilai rata-rata siwa setelah menggunakan model student facilitator and explaining lebih tinggi 
dibandingkkan sebelum menggunakan metode ceramah yang biasa dilakukan oleh guru.

2. Seorang guru yang ingin menerapkanmodel student facilitator and explaining, harus memperhatikan keaktifan siswa dan alokasi waktu agar tujuan pembelajaran yang diharapkan tercapai.

3. Perludilakukan penelitian lanjut oleh peneliti lain, guna memberikan masukan yang membangun bagi dunia pendidikan khususnya dalam meningkatkan kemampuan berpidato.

4. Siswa disarankan agar lebih efektif mengikuti kegiatan pembelajaran yang selama ini dilaksanakan, serta lebih aktif berdiskusi yang nantinya akan menambah wawasan dan ilmu pengetahuan.

\section{DAFTAR KEPUSTAKAAN}

Arikunto, Suharsimi. 2016. Prosedur Penelitian: Suatu Pendekatan Praktik. Jakarta: Rineka Cipta.

Bahar. 2016. Seni Membawakan Pidato dan $M C$. Yogyakarta: Chivita Books.

Depdiknas. 2003. Kamus Besar Bahasa Indonesia. Jakarta: Balai Pustaka.

Pemungkas. 2002. Berbagai Bahasa Indonesia Dalam Perspektif. Yogyakarta: Andi.

Mira. 2012. GarutModel Pembelajaran dengan Menggunakan Model Impromtu Pada Siswa Kelas VIII SMP PGRI Karangpawitan

Rusman. 2012. Model-Model Pembelajaran. Jakarta: PT. Rajagrafindo Persada.

Sihotang. 2014. Pengaruh Model Pembelajaran Student Facilitator and Explaining terhadap kemampuan menulis Teks Berita Oleh Siswa Kelas VIII SMP Negeri 1 Bosar Maligas

Simare Mare. 2014. Efektifitas Model Pembelajaran Langsung terhadap Kemampuan Berpidato Siswa Kelas XII SMA Swasta Santa Lusia Sei Rotan

Sundayana. 2014. Statistika Penelitian Pendidikan. Bandung: Alfabeta.
Sudjana. 2005. Metode Statistika. Bandung: Tarsito.

Sudjono, Anas. 2012. Pengantar Statistik Pendidikan. Jakarta: Rajawali Pers.

Sugiyono. 2012. Metode Penelitian Pendidikan (Pendekatan Kuantitatif, Kualitatif, Bandung: Alfabeta.

Sukmadinata, Nana Syaodih. 2012. Metode Penelitian Pendidikan. Bandung: PT Remaja Rosdakarya.

Sumarna. 2016. Naskah Pidato. Klaten: Cable Book.

Henry Guntur. 2008. Berbicara Sebagai Suatu Ketrampilan Berbahasa.

Bandung: Angkasa 